PROFIL USAHATANI JERUK PAMELO GIRI MATANG (Citrus maxima (Burm.) Merr) DI KECAMATAN PEUSANGAN SIBLAH KRUENG, KABUPATEN BIREUEN

(Farming Profile of Giri Matang Pummelo (Citrus maxima (Burm) Merr.) in Peusangan Siblah Krueng District, Bireuen Regency)

\author{
Andya Safrizal ${ }^{1}$, Irwan A. Kadir ${ }^{1}$, Ahmad Humam Hamid ${ }^{1 *}$ \\ ${ }^{1}$ Program Studi Agribisnis, Fakultas Pertanian, Universitas Syiah Kuala
}

\begin{abstract}
Abstrak - Profil usahatani jeruk pamelo giri matang merupakan suatu gambaran mengenai keberadaan usahatani komoditas tanaman jeruk pamelo kultivar giri matang (putih manis) berdasarkan skala budidaya tertentu, jumlah populasi berdasarkan stadia umur tanaman, luas tanam, status kepemilikan tanaman dan seluruh aspek kegiatan pembudidayaannya. Penelitian ini bertujuan untuk mengetahui bagaimana standar ideal usahatani, rantai saluran pemasaran, dan jenis pendapatan yang diperoleh rumah tangga petani dari usahatani jeruk pamelo giri matang di Kecamatan peusangan Siblah Krueng. Hasil penelitian menunjukan bahwa usahatani jeruk pamelo giri matang belum memenuhi standar usahatani ideal, karena sebagian besar rumah tangga petani belum menerapkan kegiatan usahatani sesuai dengan standar. Pemasaran jeruk pamelo giri matang menggunakan saluran pemasaran 0 dan 1 tingkat. Usahatani jeruk pamelo giri matang bukan merupakan sumber pendapatan utama rumah tangga petani, karena kontribusinya tergolong dalam kategori rendah yaitu sebesar $16 \%$ dengan rata-rata pendapatan $\mathrm{Rp} 11.511 .003 /$ tahun.
\end{abstract}

Kata kunci: Profil, Jeruk Pamelo, Saluran Pemasaran, Pendapatan

Abstract - Farming profile of giri matang pummelo is an illustration of the existence of pummelo crops farming commodity of giri matang (sweet white) cultivar based on a certain scale cultivation, the number of population by crop age stadia, acreage, ownership status of plants and all the aspect of cultivation. This study aims to determine how the ideal standard of farming, marketing channel chain, and the type of farmer household income derived from the farming of giri matang pummelo in Peusangan Siblah Krueng distric. The results showed that the farming of giri matang pummelo has not met the ideal standard of farming, because most of farmers household do not apply farming activities in accordance with the standard. Giri matang pummelo marketing using marketing channels 0 and 1 levels. Farming of giri matang pummelo is not the main source of income of farmer households, for his contributions

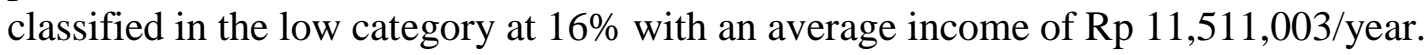

Keywords: Profile, Pummelo, Marketing Channel, Income

\title{
PENDAHULUAN
}

Pamelo (Citrus maxima (Burm.) Merr) atau jeruk besar merupakan salah satu jenis tanaman hortikultura yang mendapat perhatian dari pemerintah untuk dikembangkan dan ditingkatkan produksinya karena memiliki prospek pemasaran yang baik dan dapat menjadi sumber perekonomian regional maupun nasional serta dapat membantu meningkatkan gizi masyarakat (Isaskar $d k k, 2011$ ). Hal ini ditunjukkan berdasarkan peningkatan produksi jeruk pamelo nasional dari tahun 2010 sebesar 91.131 ton menjadi 141.288 ton pada tahun 2014 dengan pertumbuhan produksi sebesar 32,87 \% (BPS dan Dirjen Hortikultura, 2015). Jeruk ini 
mempunyai karakter yang khas yaitu buahnya berukuran besar, memiliki rasa segar dan daya simpan lama sampai empat bulan (Susanto, 2004).

Jeruk pamelo giri matang (putih manis) merupakan salah satu kultivar unggulan pamelo yang dikembangkan di Kabupaten Bireuen, Aceh disamping 2 kultivar lain, yaitu: putih asam dan merah asam. Buah giri matang berbentuk pyriform (seperti buah pir) dengan ukuran lingkar buah antara 42-51,5 cm dan bobot per buah antara 1,1-1,6 kg. Kulit buah bagian luar berwarna kuning, tebal 0,75-1,50 mm, tebal kulit bagian dalam 10,05-19,75 mm dan jumlah biji 0-10 per buah. Daging buah lembut, berwarna putih dengan rasa manis. Keunggulan pamelo giri matang antara lain dapat berbuah sepanjang tahun, tergolong tidak berbiji $(<10$ biji/buah), kulit buahnya mudah dikupas, daya simpan lama, dan tanaman mampu beradaptasi dengan baik di dataran rendah (Susanto $d k k, 2013$ ).

Kecamatan Peusangan Siblah Krueng merupakan salah satu daerah sentra produksi jeruk pamelo di Kabupaten Bireuen. Untuk mengetahui gambaran tanaman jeruk pamelo giri matang di Kabupaten Bireuen menurut kecamatan, dapat dilihat pada Tabel 1.

Tabel 1. Jumlah Tanaman, Tanaman Menghasilkan, Produktivitas dan Produksi Jeruk Pamelo Giri Matang Menurut Kecamatan di Kabupaten Bireuen Tahun 2014

\begin{tabular}{|c|l|c|c|c|c|}
\hline No & Kecamatan & $\begin{array}{c}\text { Jumlah } \\
\text { Tanaman } \\
\text { Jeruk Pamelo } \\
\text { (Batang) }\end{array}$ & $\begin{array}{c}\text { Tanaman } \\
\text { Jeruk Pamelo } \\
\text { Menghasilkan } \\
\text { (Batang) }\end{array}$ & $\begin{array}{c}\text { Produktivitas } \\
\text { (Kw) }\end{array}$ & $\begin{array}{c}\text { Produksi } \\
\text { (Ton) }\end{array}$ \\
\hline 1 & Samalanga & 475 & 125 & 1,69 & 21,10 \\
\hline 2 & Simpang Mamplam & 665 & - & - & - \\
\hline 3 & Pandrah & 75 & - & - & - \\
\hline 4 & Jeunieb & 190 & 130 & 0,60 & 7,80 \\
\hline 5 & Peulimbang & 118 & 50 & 1,42 & 7,10 \\
\hline 6 & Peudada & 1.923 & 425 & 2,08 & 88,10 \\
\hline 7 & Juli & 1.594 & 217 & 1,25 & 2,70 \\
\hline 8 & Jeumpa & 1.215 & 125 & 1,87 & 39,20 \\
\hline 9 & Kota Juang & 1.080 & 210 & 1,23 & 62,90 \\
\hline 10 & Kuala & 466 & 94 & 2,03 & 11,50 \\
\hline 11 & Jangka & 10.439 & 2.200 & 2,49 & 445,80 \\
\hline 12 & Peusangan & 23.843 & 11.500 & 1,60 & 2861,30 \\
\hline 13 & Peusangan Selatan & 8.306 & 3.270 & 2,24 & 523,20 \\
\hline 14 & Peusangan Sb. Krueng & 18.360 & 11.850 & 1,64 & 2664,50 \\
\hline 15 & Makmur & 183 & 79 & 1,44 & 12,90 \\
\hline 16 & Gandapura & 3.345 & 4.574 & 0,32 & 656,40 \\
\hline 17 & Kuta Blang & 8.853 & 7.700 & 0,95 & 2400,00 \\
\hline & Jumlah & $\mathbf{8 1 . 1 3 0}$ & $\mathbf{4 2 . 5 4 9}$ & $\mathbf{2 2 , 8 5}$ & $\mathbf{9 8 0 4 , 5 0}$ \\
\hline
\end{tabular}

Sumber: Dinas Pertanian dan Peternakan Kabupaten Bireuen, 2015.

Berdasarkan data pada tabel diatas, dapat dilihat bahwa pada tahun 2014 dapat dilihat bahwa produksi terbesar jeruk pamelo terdapat di Kecamatan Peusangan dengan produksi 
sebanyak 2861,30 ton, sedangkan Kecamatan Peusangan Siblah Krueng menempati urutan kedua dengan jumlah produksi sebanyak 2664,50 ton. Pemilihan Kecamatan Peusangan Siblah Krueng sebagai lokasi penelitian karena Kecamatan ini memiliki jumlah tanaman menghasilkan terbesar di Kabupaten Bireuen, yaitu sebanyak 11.850 batang. Selain itu, daerah Kecamatan Peusangan Siblah Krueng memiliki iklim tropis, dengan ketinggian 0-969 mdpl, suhu udara berkisar antara $23^{\circ} \mathrm{C}-34^{\circ} \mathrm{C}$, kelembaban 60-70\% dan $\mathrm{pH}$ tanah 5,5-7,0 yang sangat cocok untuk pertumbuhan tanaman jeruk pamelo yang tumbuh baik pada iklim tropis dengan ketinggian $400 \mathrm{mdpl}$, suhu udara rata-rata berkisar antara $25-30^{\circ} \mathrm{C}$, kelembaban 50 $85 \%$ dan $\mathrm{pH}$ tanah 5-6.

Di Kecamatan Peusangan Siblah Krueng tanaman jeruk pamelo tumbuh dengan subur diarea pekarangan rumah penduduk. Selain sebagai sumber ekonomi pendapatan rumah tangga, penanaman tanaman ini juga dapat bermanfaat memberikan suasana teduh dihalaman rumah. Namun, keberadaan populasi tanaman jeruk pamelo giri matang saat ini semakin berkurang akibat pengurangan lahan pekarangan untuk pembangunan rumah, sehingga menyebabkan banyaknya pohon yang ditebang. Kondisi tersebut menyebabkan keberadaan habitat asli tanaman jeruk pamelo giri matang ini semakin terancam punah.

Upaya perbanyakan populasi tanaman dan pengebunan tanaman jeruk pamelo giri matang merupakan salah satu cara untuk menjaga kelestarian habitat asli tanaman jeruk pamelo giri matang dari kepunahan. Menurut Purwanto, $d k k$ (2002), pelestarian tanaman jeruk pamelo perlu dilakukan agar varietas asli tanaman tidak punah dan menjadi sumber genetik dalam menciptakan varietas unggul baru. Selain itu, masih belum diketahui secara pasti bagaimana status kepemilikan dari tanaman yang diusahakan tersebut. Apakah tanaman jeruk pamelo tersebut tumbuh secara alami, warisan secara turun temurun atau hasil budidaya yang dilakukan sendiri.

Adapun permasalahan dalam penelitian ini, yaitu: Bagaimana standar ideal usahatani, saluran pemasaran dan jenis pendapatan yang diperoleh rumah tangga petani dari usahatani jeruk pamelo giri matang di Kecamatan Peusangan Siblah Krueng, Kabupaten Bireuen

Tujuan penelitian ini adalah untuk mengetahui standar ideal usahatani jeruk pamelo giri matang, saluran pemasaran dan jenis pendapatan yang diterima rumah tangga petani dari usahatani jeruk pamelo giri matang di Kecamatan Peusangan Siblah Krueng, Kabuaten Bireuen.

\section{METODOLOGI PENELITIAN}

Penelitian ini dilakukan di Kecamatan Peusangan Siblah Krueng, Kabupaten Bireuen. Pemilihan lokasi dilakukan dengan sengaja (Purposive Sampling), dengan pertimbangan bahwa daerah tersebut merupakan salah satu kawasan sentra produksi jeruk pamelo giri matang di Kabupaten Bireuen. Objek dalam penelitian ini adalah rumah tangga yang memiliki tanaman jeruk pamelo giri matang. Adapun ruang lingkup penelitian hanya terbatas pada profil usahatani jeruk pamelo giri matang di Kecamatan Peusangan Siblah Krueng, Kabupaten Bireuen.

Jenis data yang digunakan dalam penelitian ini yaitu data primer dan data sekunder. Data primer diperoleh dari pengamatan dan wawancara langsung dengan responden, sedangkan data sekunder digunakan untuk mendukung data primer yang diperoleh dari lembaga, instansi, buku, jurnal dan laporan yang berhubungan dengan penelitian.

Populasi dalam penelitian ini adalah rumah tangga petani yang memiliki tanaman jeruk pamelo giri matang di Kecamatan Peusangan Siblah Krueng, Kabupaten Bireuen. Penentuan lokasi penelitian dilakukan dengan menggunakan metode acak sederhana (Simple Random Sampling), dengan memilih 4 desa dari jumlah 12 desa yang mayoritas rumah tangga 
petaninya membudidayakan tanaman jeruk pamelo sebagai lokasi penelitian, dengan pertimbangan bahwa 4 desa tersebut memiliki jumlah populasi rumah tangga petani dan luas tanam jeruk pamelo terbesar di Kecamatan Peusangan Siblah Krueng.

Pada penelitian ini jumlah sampel diambil 10\% dari jumlah populasi (KK) petani jeruk pamelo giri matang yang terdapat pada masing-masing desa penelitian. Arikunto (2002), menyatakan apabila jumlah populasi lebih dari 100 dapat diambil $10-15 \%$ atau $20-25 \%$ atau lebih. Jumlah sampel petani jeruk pamelo giri matang dalam penelitian ini adalah $30 \mathrm{KK}$ rumah tangga petani yang terbagi dalam 4 desa di Kecamatan Peusangan Siblah Krueng, yaitu Desa Lueng Daneun sebanyak 7 KK, Desa Pante Baro Kumbang sebanyak 8 KK, Desa Kubu Sebanyak 9 KK dan Desa Teupin Raya sebanyak 6 KK.

Metode analisis yang digunakan penelitian ini adalah metode analisis deskriptif kuantitatif. Untuk mengukur standar usahatani ideal digunakan metode deskriptif dengan membandingkan antara standar usahatani ideal berdasarkan teori dan kegiatan usahatani yang dilakukan oleh rumah tangga petani dengan menggunakan tabel perbandingan.

Rantai saluran pemasaran buah jeruk pamelo giri matang dapat diukur dengan menggunakan metode deskriptif berdasarkan tingkatan saluran pemasaran dari petani hingga produk sampai ke konsumen akhir, yang terbagi atas 4 tingkatan saluran pemasaran, yaitu:

a) Saluran Pemasaran 0 Tingkat: (Produsen=> Konsumen).

b) Saluran Pemasaran 1 Tingkat: (Petani $=>$ Pedagang Pengecer $=>$ Konsumen).

c) Saluran Pemasaran 2 Tingkat: (Petani $=>$ Pedagang Besar $=>$ Pedagang Pengecer $=>$ Konsumen).

d) Saluran Pemasaran 3 Tingkat: (Petani=> Agen=> Pedagang Besar=> Pedagang Pengecer $=>$ Konsumen) (Keegan, 2003).

Untuk mengetahui jenis pendapatan usahatani jeruk pamelo giri matang, dapat digunakan analisis penerimaan, biaya produksi, pendapatan dan kontribusi sebagai berikut:

\section{Analisis Penerimaan}

$\mathrm{TR}=\mathrm{P} \times \mathrm{Q}$. .(Sukirno, 2003).

Dimana:

$\mathrm{TR}=$ Total penerimaan $(\mathrm{Rp} /$ panen $)$.

$\mathrm{P}=\operatorname{Harga}(\mathrm{Rp} / \mathrm{buah})$

$\mathrm{Q}=$ Jumlah penjualan (buah

Analisis Biaya Produksi

$\mathrm{TC}=\mathrm{TFC}+\mathrm{TVC}$ .(Soekartawi, 2002).

Dimana:

$\mathrm{TC}=$ Total biaya produksi ( $\mathrm{Rp} /$ Tahun $)$

TFC $=$ Total biaya tetap (Rp/Tahun)

$\mathrm{TVC}=$ Total biaya tidak tetap $(\mathrm{Rp} / \mathrm{Tahun})$

\section{Analisis Pendapatan}

$\pi=\mathrm{TR}-\mathrm{TC}$ .(Sukirno, 2003).

Dimana:

$\pi=$ Pendapatan usahatani jeruk pamelo (Rp/panen).

$\mathrm{TR}=$ Total penerimaan $(\mathrm{Rp} / \mathrm{panen})$. 
$\mathrm{TC}=$ Total biaya $(\mathrm{Rp} / \mathrm{panen})$.

\section{Analisis Kontribusi Pendapatan}

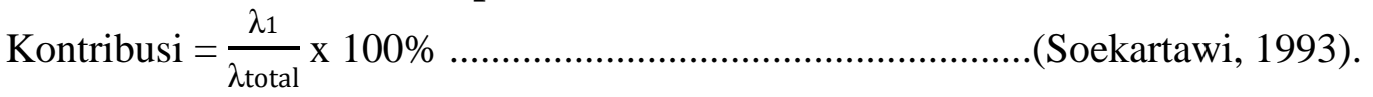

Dimana:

$\lambda_{1}=$ Pendapatan pekerjaan rumah tangga petani (Rp/Tahun).

$\lambda_{\text {total }}=$ Total pendapatan rumah tangga petani jeruk pamelo giri matang $(\mathrm{Rp} / \mathrm{Tahun})$.

Menurut Fachruddin (2011), untuk mengetahui besaran kontribusi pendapatan dapat diukur dengan kriteria, sebagai berikut:

1. Jika kontribusi pendapatan usahatani jeruk pamelo giri matang $<35 \%$ dari total pendapatan rumah tangga petani dikategorikan rendah.

2. Jika kontribusi pendapatan usahatani jeruk pamelo giri matang $>35 \%-75 \%$ dari total pendapatan rumah tangga petani dikategorikan sedang.

3. Jika kontribusi pendapatan usahatani jeruk pamelo giri matang $>75 \%$ dari total pendapatan rumah tangga petani dikategorikan tinggi.

Berdasarkan kriteria tersebut, maka dapat diambil keputusan bahwa:

1. Apabila pendapatan dari usahatani jeruk pamelo giri matang berada pada kriteria 3 , maka pendapatan tersebut merupakan pendapatan utama rumah tangga petani.

2. Apabila pendapatan dari usahatani jeruk pamelo giri matang berada pada kriteria 1 dan 2 , maka pendapatan tersebut bukan merupakan pendapatan utama rumah tangga petani.

\section{Profil Usahatani Jeruk Pamelo Giri Matang}

Jeruk Pamelo (Citrus maxima (Burm) Merr.) merupakan tanaman yang tumbuh dengan baik pada iklim tropis dengan ketinggian 400 mdpl. Untuk mengetahui gambaran profil tanaman jeruk pamelo dilokasi penelitian dapat dilihat pada Tabel 2.

Tabel 2. Profil Usahatani Jeruk Pamelo Giri Matang di Kecamatan Peusangan Siblah Krueng Tahun 2016

\begin{tabular}{|c|l|c|c|}
\hline No. & \multicolumn{1}{|c|}{ Indikator } & Satuan & Rata-rata \\
\hline 1 & Luas Tanam & $\mathrm{m}^{2}$ & 571 \\
\hline 2 & Jumlah Tanaman & Batang & 10 \\
\hline 3 & Umur Tanaman & Tahun & 17 \\
\hline
\end{tabular}

Sumber: Data Primer (Diolah) 2016.

Tabel diatas menunjukkan bahwa rata-rata luas tanam yang digunakan untuk usahatani jeruk pamelo adalah $571 \mathrm{~m}^{2}$ dengan rata-rata jumlah kepemilikan tanaman sebanyak 10 batang dan umur rata-rata tanaman 17 tahun. Luas tanam dan jumlah tanaman yang masih sedikit ini dikarenakan rata-rata rumah tangga petani dilokasi penelitian memiliki lahan pekarangan yang sempit dan hanya sedikit dari rumah tangga petani yang membudidayakannya dikebun, karena tanaman ini umumnya ditanam dipekarangan rumah sebagai tanaman peneduh, sedangkan jika dilihat dari usia tanaman sudah sangat produktif, karena produktivitas tanaman jeruk pamelo untuk menghasilkan buah sudah terlihat sejak tanaman memasuki usia 3-4 tahun dari masa penanaman. Untuk mengetahui bagaimana status 
tanaman jeruk pamelo giri matang yang diusahakan oleh rumah rumah tangga petani dilokasi penelitian, dapat dilihat pada Tabel 3 .

Tabel 3. Gambaran Status Tanaman Jeruk Pamelo Giri Matang di Kecamatan Peusangan Siblah Krueng Tahun 2016.

\begin{tabular}{|r|l|c|c|}
\hline No. & \multicolumn{1}{|c|}{ Status Tanaman } & $\begin{array}{c}\text { Frekuensi } \\
(\mathrm{n})\end{array}$ & $\begin{array}{c}\text { Persentase } \\
(\%)\end{array}$ \\
\hline 1 & Tumbuh Alami & 0 & 0 \\
\hline 2 & Dibudidayakan & 27 & 90 \\
\hline 3 & Warisan & 3 & 10 \\
\hline & Jumlah & 30 & 100 \\
\hline
\end{tabular}

Sumber: Data Primer (Diolah) 2016.

Berdasarkan data pada tabel diatas, dapat dilihat bahwa ditinjau dari statusnya, tanaman yang berstatus dibudidayakan memiliki jumlah sampel terbanyak, yaitu sebesar 27 orang atau $90 \%$, sedangkan tanaman yang berstatus warisan memiliki jumlah sampel sebanyak 3 orang atau $10 \%$. Pada tanaman yang berstatus warisan merupakan warisan yang diberikan orang tua kepada anaknya untuk melanjutkan usaha budidaya yang mencakup perawatan dan pemeliharaan tanaman jeruk pamelo untuk dimanfaatkan hasilnya sebagai konsumsi dan sumber tambahan pendapatan keluarga.

\section{Gambaran Budidaya Tanaman Jeruk Pamelo Giri Matang}

Dalam budidaya tanaman jeruk pamelo pada fase tanaman menghasilkan mencakup kegiatan pemeliharaan, yang meliputi: penyiangan gulma, pemangkasan, pemupukan, penyiraman, pembubunan, pengendalian OPT dan penjarangan buah. Untuk mengetahui gambaran penerapan kegiatan budidaya tanaman jeruk pamelo giri matang dilokasi penelitian dapat dilihat berdasarkan perbandingan antara standar usahatani ideal dengan penerapan kegiatan yang dilakukan oleh rumah tangga petani pada sajian Tabel 4.

Tabel 4. Perbandingan Antara Usahatani Ideal dan Penerapan Kegiatan Budidaya yang Dilakukan Oleh Rumah Tangga Petani Jeruk Pamelo Giri Matang di Kecamatan Peusangan Siblah Krueng Tahun 2016.

\begin{tabular}{|c|l|l|l|}
\hline No & \multicolumn{1}{|c|}{ Indikator } & \multicolumn{2}{|c|}{ Profil Usahatani } \\
\cline { 3 - 4 } & $\begin{array}{l}\text { Penyiangan } \\
\text { Gulma }\end{array}$ & $\begin{array}{l}\text { Penyiangan gulma dilakukan secara } \\
\text { periodik 3-4 kali dalam setahun baik } \\
\text { dengan menggunakan cara manual dan } \\
\text { penggunaan pestisida sebagai } \\
\text { alternatif terakhir jika cara alami tidak } \\
\text { berhasil (Mulyanto, 2015). }\end{array}$ & $\begin{array}{l}\text { Penyiangan gulma dilakukan } \\
\text { tidak secara periodik } \\
\text { berdasarkan kondisi } \\
\text { perkembangan gulma dilapangan } \\
\text { dengan menggunakan cara } \\
\text { manual }\end{array}$ \\
\hline 2 & Pemangkasan & $\begin{array}{l}\text { Pemangkasan pemeliharaan dilakukan } \\
\text { pada setiap permulaan musim hujan } \\
\text { dan setelah panen untuk memacu } \\
\text { pertumbuhan tanaman dan } \\
\text { pembungaan dengan memotong tunas- } \\
\text { tunas air, cabang atau ranting yang } \\
\text { terlalu rimbun, ranting kering atau } \\
\text { yang sakit dan tangkai buah yang telah } \\
\text { dipanen (Yulizar, 2015). }\end{array}$ & $\begin{array}{l}\text { Pemangkasan pemeliharaan } \\
\text { dilakukan ketika cabang dan } \\
\text { ranting tanaman sudah terlalu } \\
\text { rimbun dengan memotong } \\
\text { cabang-cabang yang tidak } \\
\text { produktif dan bagian tanaman } \\
\text { yang terserang hama penyakit }\end{array}$ \\
\hline
\end{tabular}




\begin{tabular}{|c|c|c|c|}
\hline 3 & Pemupukan & $\begin{array}{l}\text { Pemupukan pada tanaman yang telah } \\
\text { berumur }>8 \text { tahun dilakukan } 2 \text { kali } \\
\text { dalam setahun setelah panen dan } \\
\text { pemangkasan dengan takaran untuk } \\
\text { pupuk kandang sebanyak } 0,75-1,00 \\
\text { kg/pohon/tahun dan dosis penggunaan } \\
\text { pupuk anorganik dihitung 2-3\% dari } \\
\text { total bobot buah yang dipanen } \\
\text { (Sundari, 2011). }\end{array}$ & $\begin{array}{l}\text { Pemupukan pada tanaman yang } \\
\text { telah berumur }>8 \text { tahun } \\
\text { dilakukan } 2 \text { kali dalam setahun } \\
\text { dengan takaran untuk pupuk } \\
\text { organik dan anorganik } \\
\text { berdasarkan perkiraan }\end{array}$ \\
\hline 4 & Penyiraman & $\begin{array}{l}\text { Penyiraman efektif pada budidaya } \\
\text { tanaman dalam skala kecil dilakukan } \\
\text { 2-3 kali dalam seminggu dengan } \\
\text { menyiramkan air langsung kesetiap } \\
\text { pohon dengan menggunakan selang air } \\
\text { atau alat penyiram lainnya, kecuali } \\
\text { pada saat musim hujan penyiraman } \\
\text { tidak dilakukan. (Sundari, 2011). }\end{array}$ & $\begin{array}{l}\text { Penyiraman dilakukan seminggu } \\
\text { sekali dengan menyiramkan air } \\
\text { langsung pada tanaman dengan } \\
\text { menggunakan selang air atau } \\
\text { timba. Pada saat musim hujan } \\
\text { penyiraman tidak dilakukan }\end{array}$ \\
\hline 5 & Pembubunan & $\begin{array}{l}\text { Pembubunan dilakukan minimal } 2 \text { kali } \\
\text { dalam setahun, yaitu pada awal musim } \\
\text { hujan dan akhir musim hujan (Dinas } \\
\text { Pertanian dan Ketahanan Pangan, } \\
\text { 2006). }\end{array}$ & $\begin{array}{l}\text { Pembubunan biasanya dilakukan } \\
\text { sekali dalam setahun setelah } \\
\text { musim hujan untuk meninggikan } \\
\text { tanah disekitar area perakaran } \\
\text { yang telah terkikis oleh air hujan }\end{array}$ \\
\hline 6 & $\begin{array}{l}\text { Pengendalian } \\
\text { OPT }\end{array}$ & $\begin{array}{l}\text { Tindakan pengendalian OPT } \\
\text { dilakukan secara sistematis dengan } \\
\text { menyemprotkan herbisida sebanyak 1- } \\
2 \text { kali dalam setahun atau secara } \\
\text { manual setiap 2-3 kali dalam } \\
\text { seminggu dengan mengasapi tanaman } \\
\text { dan membakar ranting-ranting } \\
\text { tanaman, sedangkan pengendalian } \\
\text { hama penyakit pada buah dilakukan } \\
\text { dengan cara memetik buah yang } \\
\text { terserang kemudian dibenam dalam } \\
\text { tanah atau dibakar, pemasangan } \\
\text { perangkap lalat buah, metil eugenol } \\
\text { dan penyemprotan insektisida sesuai } \\
\text { anjuran (Thamrin dkk, 2013). }\end{array}$ & $\begin{array}{l}\text { Tindakan pengendalian OPT } \\
\text { dilakukan secara alami minimal } \\
\text { sekali dalam seminggu dengan } \\
\text { mengasapi tanaman, membakar } \\
\text { sisa-sisa sampah dedaunan dan } \\
\text { ranting tanaman, memotong } \\
\text { bagian tanaman yang terserang } \\
\text { hama dan penyakit sedangkan } \\
\text { pengendalian hama dan penyakit } \\
\text { pada buah dilakukan dengan } \\
\text { membungkus buah dengan } \\
\text { keranjang buah atau kantong } \\
\text { plastik }\end{array}$ \\
\hline 7 & $\begin{array}{l}\text { Penjarangan } \\
\text { buah }\end{array}$ & $\begin{array}{l}\text { Penjarangan buah dilakukan dengan } \\
\text { memotong buah yang cacat, terserang } \\
\text { hama penyakit dan berukuran kecil } \\
\text { dengan menggunakan gunting dan } \\
\text { menyisakan } 2-3 \text { buah per pucuk } \\
\text { cabang atau tandan (Sutopo, } 2015 \text { ). }\end{array}$ & $\begin{array}{l}\text { Penjarangan buah dilakukan } \\
\text { dengan membuang buah jantan }\end{array}$ \\
\hline
\end{tabular}

Sumber: Data Sekunder dan Primer (Diolah), 2016.

Berdasarkan tabel diatas, dapat diketahui bahwa penerapan kegiatan budidaya tanaman jeruk pamelo giri matang yang dilakukan oleh rumah tangga petani dilokasi penelitian belum sesuai dengan standar usahatani ideal, karena rata-rata kegiatan dilakukan secara tidak menentu tanpa memperhatikan waktu penerapan yang tepat. 
Kegiatan yang dilakukan oleh rumah tangga petani dilokasi penelitian antara lain: pengendalian gulma yang dilakukan tidak secara periodik berdasarkan kondisi perkembangan gulma dilapangan dengan menggunakan cara manual, sedangkan berdasarkan standar usahatani ideal penyiangan gulma dilakukan secara periodik 3-4 kali dalam setahun baik dengan menggunakan cara manual dan penggunaan pestisida sebagai alternatif terakhir, jika cara alami tidak berhasil (Mulyanto, 2015). Pemangkasan tanaman dilakukan ketika cabang dan ranting tanaman sudah terlalu rimbun dengan memotong cabang-cabang yang tidak produktif dan bagian tanaman yang terserang hama penyakit, sedangkan berdasarkan standar usahatani ideal, pemangkasan pemeliharaan dilakukan pada setiap permulaan musim hujan untuk memacu pertumbuhan tanaman dan pembungaan dengan memotong tunas-tunas air, cabang atau ranting yang terlalu rimbun, ranting kering atau yang sakit dan tangkai buah yang telah dipanen (Yulizar, 2015).

Pemupukan yang dilakukan sebanyak 2 kali dalam setahun dengan takaran berdasarkan perkiraan dan tanpa memperhatikan dosis pemupukan sesuai anjuran berdasarkan standar usahatani ideal, yaitu $0,75-1,00 \mathrm{~kg} /$ pohon/tahun untuk pupuk organik dan pupuk anorganik dihitung 2-3\% dari total bobot buah yang dipanen untuk tanaman jeruk pamelo yang telah berumur $>8$ tahun (Sutopo, 2015). Penyiraman dilakukan seminggu sekali dengan menyiramkan air langsung pada tanaman dengan menggunakan selang air dan timba, sedangkan berdasarkan standar usahatani ideal, penyiraman yang baik dilakukan sebanyak 2-3 kali dalam seminggu untuk menjaga kelembaban tanah dan mensupplai kebutuhan air tanaman (Sundari, 2011). Pembubunan dilakukan sekali dalam setahun, yaitu setelah musim hujan untuk meninggikan tanah disekitar area perakaran yang telah terkikis oleh air hujan dan tidak sesuai dengan standar usahatani ideal yang seharusnya dilakukan 2 kali dalam setahun, yaitu pada awal musim hujan dan akhir musim hujan (Dinas Pertanian dan Ketahanan Pangan, 2006).

Pengendalian OPT dilakukan secara alami 2-3 kali dalam seminggu dengan mengasapi tanaman dengan membakar sisa-sisa sampah dedaunan dan ranting tanaman, memotong bagian tanaman yang terserang hama dan penyakit, sedangkan pengendalian hama dan penyakit pada buah dilakukan dengan membungkus buah dengan menggunakan keranjang buah atau kantong plastik, sedangkan berdasarkan standar usahatani ideal, pengendalian OPT dilakukan secara sistematis dengan menyemprotkan herbisida sebanyak 1-2 kali dalam setahun atau secara manual dengan mengasapi tanaman dan membakar ranting-ranting tanaman, sedangkan pengendalian hama penyakit pada buah (penggerek dan lalat buah) dilakukan dengan cara memetik buah yang terserang kemudian dibenam dalam tanah atau dibakar, serta dilakukan pemasangan perangkap lalat buah, metil eugenol dan penyemprotan insektisida sesuai anjuran (Thamrin $d k k, 2013$ ).

Penjarangan buah yang dilakukan yaitu dengan membuang buah jantan, sedangkan berdasarkan standar usahatani ideal penjarangan buah dilakukan dengan memotong buah yang cacat, terserang hama penyakit dan berukuran kecil dengan menggunakan gunting dan menyisakan 2-3 buah per pucuk cabang atau tandan (Sutopo, 2015). Selanjutnya untuk mengetahui persentase penerapan kegiatan budidaya tanaman jeruk pamelo giri matang oleh rumah tangga petani dilokasi penelitian dapat dilihat pada Tabel 5.

Berdasarkan data pada Tabel 5, dapat diketahui bahwa kegiatan penyiangan gulma, pemangkasan, pemupukan, penyiraman, pembubunan, pengendalian OPT dan penjarangan buah yang diterapkan oleh sebagian besar rumah tangga petani sesuai dengan standar usahatani ideal. Hal ini menunjukkan bahwa penerapan kegiatan usahatani jeruk pamelo giri matang dilokasi penelitian belum memenuhi standar usahatani ideal, karena jumlah rumah tangga petani yang menerapkan kegiatan budidaya tanaman jeruk pamelo giri matang tidak 
sesuai dengan standar usahatani ideal lebih banyak dari pada yang menerapkan sesuai dengan standar usahatani ideal.

Tabel 5. Penerapan Kegiatan Budidaya Oleh Rumah Tangga Petani di Kecamatan Peusangan Siblah Krueng Tahun 2016.

\begin{tabular}{|c|l|c|c|c|c|}
\hline \multirow{2}{*}{ No } & \multirow{2}{*}{ Indikator Kegiatan } & \multicolumn{5}{|c|}{ Standar Usahatani Ideal } \\
\cline { 3 - 6 } & & Sesuai & $\begin{array}{c}\text { Persentase } \\
(\%)\end{array}$ & $\begin{array}{c}\text { Tidak } \\
\text { Sesuai }\end{array}$ & Persentase (\%) \\
\hline 1 & Penyiangan Gulma & 3 & 10 & 27 & 90 \\
\hline 2 & Pemangkasan & 6 & 20 & 24 & 80 \\
\hline 3 & Pemupukan & 8 & 27 & 22 & 90 \\
\hline 4 & Penyiraman & 10 & 33 & 20 & 67 \\
\hline 5 & Pembubunan & 10 & 33 & 20 & 70 \\
\hline 6 & Pengendalian OPT & 9 & 30 & 21 & 100 \\
\hline 7 & Penjarangan Buah & 0 & 0 & 30 & 67 \\
\hline
\end{tabular}

Sumber: Data Primer (Diolah), 2016.

\section{Pendapatan Usahatani Jeruk Pamelo Giri Matang}

Pendapatan dari usahatani jeruk pamelo giri matang diperoleh berdasarkan total hasil produksi buah yang dihasilkan selama setahun setelah dikurangi dengan biaya produksi yang digunakan selama proses produksi usahatani berlangsung. Untuk mengetahui rata-rata pendapatan bersih rumah tangga petani yang diperoleh dari usahatani jeruk pamelo giri matang dilokasi penelitian dapat dilihat pada Tabel 6.

Tabel 6. Rata-Rata Pendapatan Rumah Tangga Petani Dari Usahatani Jeruk Pamelo Giri Matang di Kecamatan Peusangan Siblah Krueng Tahun 2016

\begin{tabular}{|r|l|rr|}
\hline No. & \multicolumn{1}{|c|}{ Uraian } & \multicolumn{2}{|c|}{$\begin{array}{c}\text { Pendapatan } \\
\text { (Rp/Tahun) }\end{array}$} \\
\hline 1 & Total Produksi & & 17.650 .000 \\
\hline 2 & Total Biaya Produksi & & 6.133 .997 \\
\hline 3 & Pendapatan & & 11.511 .003 \\
\hline
\end{tabular}

Sumber: Data Primer (Diolah), 2016.

Berdasarkan tabel diatas tabel diatas dapat diketahui bahwa rata-rata total pendapatan bersih yang diterima rumah tangga petani dari usahatani jeruk pamelo giri matang adalah $\mathrm{Rp}$ 11.511.003/tahun. Hal ini menunjukkan bahwa usahatani yang dilakukan menguntungkan, karena mampu menutupi seluruh biaya yang digunakan selama proses produksi usahatani serta mampu menyisakan pendapatan sebagai bentuk keuntungan yang merupakan pendapatan bersih rumah tangga petani yang diperoleh dari usahatani jeruk pamelo setelah dikurangi dengan total biaya produksi selama setahun. 


\section{Rantai Saluran Pemasaran Jeruk Pamelo Giri Matang}

Pemasaran buah jeruk pamelo giri matang yang dilakukan rumah tangga petani menggunakan saluran pemasaran 0 dan 1 tingkat. Untuk mengetahui gambaran rantai saluran pemasaran 0 tingkat jeruk pamelo giri matang dari petani kekonsumen dapat dilihat pada Gambar 1.

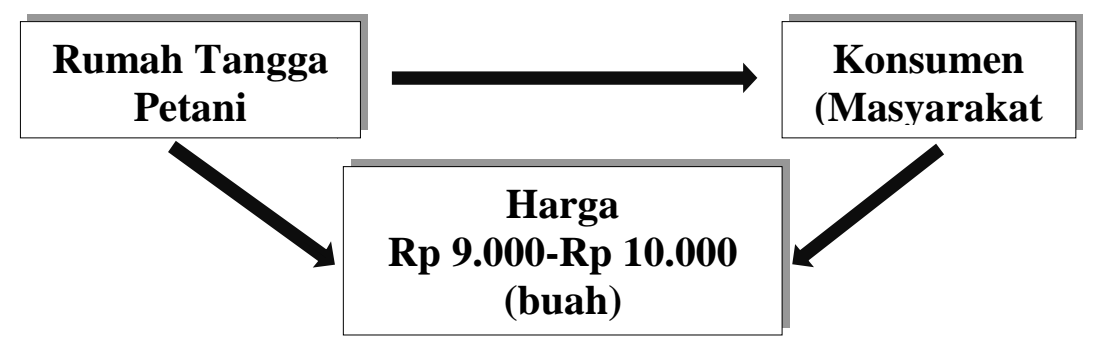

Gambar 1. Rantai saluran pemasaran 0 tingkat pada buah jeruk pamelo giri matang

Pada saluran pemasaran 0 tingkat, konsumen yang datang ke rumah membeli buah jeruk pamelo pada rumah tangga petani yang berjumlah beberapa buah saja untuk dikonsumsi sendiri atau untuk dikirimkan kepada anak dan kerabatnya yang berada diluar daerah. Harga yang ditawarkan oleh rumah tangga petani kepada konsumen yaitu sebesar Rp 9.000-10.000. Harga ini relatif lebih murah dan terjangkau dari pada harga dipasar yang lebih mahal karena telah melewati beberapa tahap saluran pemasaran.

Selanjutnya untukntuk mengetahui gambaran rantai saluran pemasaran 1 tingkat jeruk pamelo giri matang dari petani kekonsumen dapat dilihat pada Gambar 2.

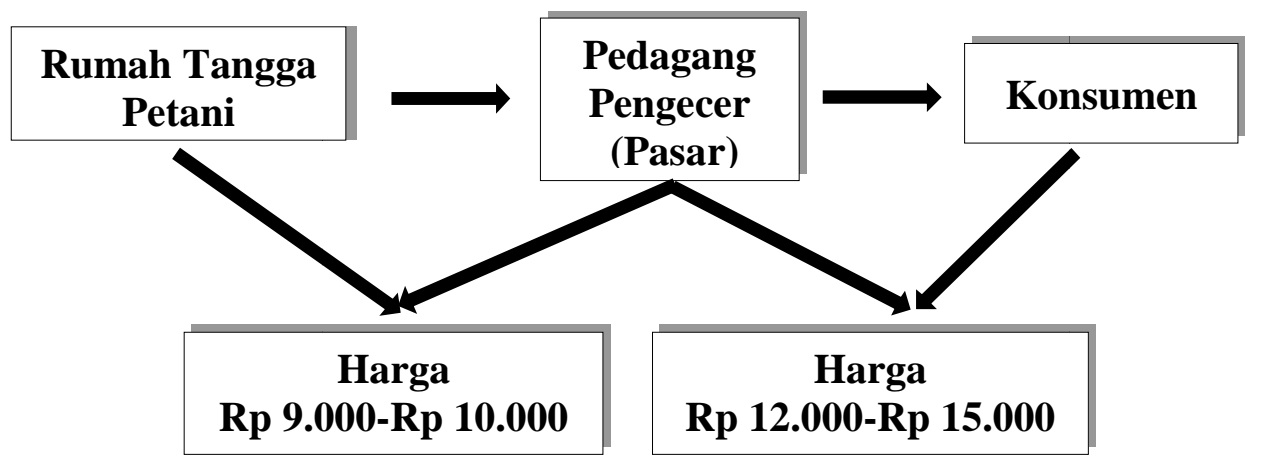

Gambar 2. Rantai saluran pemasaran 1 tingkat pada buah jeruk pamelo giri matang

Berdasarkan gambar diatas, dapat diketahui bahwa pada saluran pemasaran 1 tingkat yang digunakan dalam pemasaran buah jeruk pamelo bermula dari rumah tangga petani jeruk pamelo yang menjual buah jeruk pamelo kepedagang pengecer dengan harga yang berkisar antara Rp 9.000-Rp 10.000/buah. Kemudian, dari pedagang pengecer buah dijual kembali kekonsumen setelah dibawa kepasar dengan harga yang lebih tinggi, yaitu $\mathrm{Rp}$ 12.000-Rp 15.000/buah. Hal ini menunjukkan bahwa ada selisih perbedaan harga $\mathrm{Rp}$ 2.000-Rp $5.000 /$ buah antar lembaga pemasaran yang dilalui.

Pemasaran jeruk pamelo yang diperoleh pedagang pengecer dari setiap rumah tangga petani biasanya dipasarkan ke pasar Matang Glumpang II yang merupakan salah satu pusat pasar bagi 4 Kecamatan di Kabupaten Bireuen yang berdekatan dengan akses jalur perdagangan pada lintas jalan Medan-Banda Aceh, yaitu Kecamatan Peusangan, Kecamatan Peusangan Siblah Krueng, Kecamatan Peusangan Selatan dan Kecamatan Jangka. Selain pasar Matang Glumpang II, hasil produksi jeruk pamelo juga dipasarkan kepasar buah di Desa 
Pante Pisang, Kecamatan Peusangan, pasar Kuta Blang dan pasar kota Bireuen dengan ratarata harga jual yang ditawarkan berkisar antara Rp 12.000-Rp 15.000/buah.

\section{Kontribusi Pendapatan Usahatani Jeruk Pamelo Giri Matang Terhadap Pendapatan Rumah Tangga Petani}

Kontribusi pendapatan dalam penelitian ini bertujuan dapat dilihat dengan cara membandingkan persentase pendapatan yang diperoleh petani dari usahatani jeruk pamelo giri matang, sektor usahatani lainnya, sektor non-usahatani dan pendapatan anggota keluarga yang terdiri dari pendapatan suami, pendapatan isteri dan pendapatan anak, sehingga dapat ditentukan jenis pendapatan yang diperoleh rumah tangga petani dari usahatani jeruk pamelo giri matang. Untuk mengetahui persentase kontribusi pendapatan dari usahatani jeruk pamelo giri matang, sektor usahatani lainnya dan sektor non-usahatani terhadap total pendapatan rumah tangga petani dapat dilihat pada Tabel 7.

Tabel 7. Persentase Kontribusi Pendapatan Rumah Tangga Petani Jeruk Pamelo Giri Matang Dari Berbagai Sektor Usaha di Kecamatan Peusangan Siblah Krueng Tahun 2016

\begin{tabular}{|c|l|c|c|}
\hline No. & Jenis Pendapatan & $\begin{array}{c}\text { Rata-rata Pendapatan } \\
\text { (Rp/Tahun) }\end{array}$ & $\begin{array}{c}\text { Kontribusi } \\
(\%)\end{array}$ \\
\hline 1 & Jeruk Pamelo & 11.511 .003 & 16 \\
\hline 2 & Usahatani Lain & 6.629 .667 & 9 \\
\hline 3 & Non-Usahatani & 24.700 .000 & 34 \\
\hline 4 & Anggota Keluarga & 29.240 .000 & 41 \\
\hline & Jumlah & 72.080 .670 & 100 \\
\hline
\end{tabular}

Sumber : Data Primer (Diolah) 2016.

Berdasarkan tabel diatas, dapat diketahui bahwa pendapatan yang diperoleh rumah tangga petani dari usahatani jeruk pamelo giri matang bukan merupakan sumber pendapatan utama rumah tangga petani, karena hanya mampu memberikan kontribusi sebesar $16 \%$ atau Rp 11.511.003/tahun. Artinya, berdasarkan pernyataan Fachruddin (2011), bahwa pendapatan usahatani jeruk pamelo giri matang berada pada kategori rendah yaitu $<35 \%$ dan tidak termasuk kedalam jenis pendapatan utama rumah tangga petani. Hal ini menunjukkan bahwa pendapatan yang diterima rumah tangga petani dari usahatani jeruk pamelo giri matang merupakan pendapatan sampingan, karena umumnya tanaman jeruk pamelo giri matang hanya ditanam dilahan pekarangan sebagai tanaman peneduh dalam skala kecil yang terdiri dari beberapa pohon saja.

\section{KESIMPULAN DAN SARAN}

Usahatani jeruk pamelo giri matang belum memenuhi standar usahatani ideal, karena sebagian besar rumah tangga petani belum menerapkan kegiatan usahatani sesuai dengan standar. Pemasaran hasil produksi jeruk pamelo giri matang menggunakan 2 jenis saluran pemasaran, yaitu: (saluran pemasaran 0 tingkat dari rumah tangga petani ke konsumen) dan (saluran pemasaran 1 tingkat dari rumah tangga petani ke pedagang pengecer dan ke konsumen) dan usahatani jeruk pamelo giri matang bukan merupakan pendapatan utama rumah tangga petani, karena kontribusinya berada pada kategori rendah, yaitu sebesar $16 \%$ dengan rata-rata pendapatan $\mathrm{Rp} 11.511 .003 /$ tahun.

Adapun saran yang dapat diberikan dari penelitian ini, yaitu: diharapkan bagi rumah tangga petani jeruk pamelo giri matang agar dapat menerapkan kegiatan usahatani jeruk pamelo giri matang sesuai dengan standar, agar mampu menghasilkan produksi hasil panen 
buah yang optimal. Membentukan suatu lembaga atau kelompok khusus, yang menampung hasil panen buah jeruk pamelo giri matang dari rumah tangga petani, agar dapat memperpendek rantai saluran pemasaran, sehingga harga ditingkat petani menjadi lebih tinggi dan Adanya upaya pembudidayaan tanaman jeruk pamelo giri matang secara intensif, karena merupakan salah satu alternatif sumber tambahan pendapatan bagi rumah tangga petani.

\section{DAFTAR PUSTAKA}

BPS dan Dirjen Hortikultura. 2015. Produksi Buah-Buahan di Indonesia Tahun 2010-2014. Kementerian Pertanian RI. Jakarta.

Fachruddin, A. 2011. Kajian Tingkat Motivasi Nelayan Menangkap Ikan Kakap Merah Serta Kontribusinya Terhadap Total Pendapatan Keluarga Nelayan di Oesapa Kabupaten Kupang Provinsi Nusa Tenggara Timur. Fakultas pertanian Jember. Jember.

Isaskar, R., Syafrial dan Nugraha, T. W. 2011. Efisiensi Pemasaran Jeruk Pamelo Dalam Wilayah Magetan (Citrus Grandis L. Osbek). Jurnal Habitat. Volume XXII. No.1.

Keegan, W. J. 2003. Manajemen Pemasaran Global. PT. Indeks Kelompok Gramedia. Jakarta.

Purwanto, E., dkk. 2002. Identifikasi Berdasarkan Penanda Isozim terhadap Plasma Nutfah Jeruk Besar (Citrus maxima Merr.) di Blora, Jawa Tengah. Fakultas Pertanian Universitas Sebelas Maret. Surakarta.

Soekartawi. 1993. Manajemen Pemasaran Dalam Bisnis Modern. Pustaka Harapan. Jakarta. 2002. Analisis Usaha Tani. UI-Press. Jakarta.

Sukirno, S. 2003. Pengantar Teori Mikro Ekonomi. Edisi Ketiga. PT. Raja Grafindo Persada. Jakarta.

Susanto, S. 2004. Perubahan Kualitas Buah Jeruk Besar (Citrus grandis (L.) Osbeck) yang Disimpan dan Dibiarkan Di Pohon. Hayati 11: 25-29.

Susanto, S., Arifah R. dan Kartika N. T. 2013. Ragam Pamelo Indonesia. Fakultas Pertanian IPB. Bogor. 